\title{
Lumen
}

Selected Proceedings from the Canadian Society for Eighteenth-Century Studies

\section{All Shall Yield to the Mulberry Tree: Of Toothpick Cases, Punch Ladles, Tobacco Stoppers, Inkstands, Nutmeg Graters, and the Legend of Shakespeare}

\section{Jack Lynch}

Volume 29, 2010

URI : https://id.erudit.org/iderudit/1012024ar

DOI : https://doi.org/10.7202/1012024ar

Aller au sommaire du numéro

Éditeur(s)

Canadian Society for Eighteenth-Century Studies / Société canadienne d'étude du dix-huitième siècle

ISSN

1209-3696 (imprimé)

1927-8284 (numérique)

Découvrir la revue

Citer cet article

Lynch, J. (2010). All Shall Yield to the Mulberry Tree: Of Toothpick Cases, Punch

Ladles, Tobacco Stoppers, Inkstands, Nutmeg Graters, and the Legend of

Shakespeare. Lumen, 29, 21-42. https://doi.org/10.7202/1012024ar

Copyright (C Canadian Society for Eighteenth-Century Studies / Sociéte canadienne d'étude du dix-huitième siècle, 2010
Ce document est protégé par la loi sur le droit d'auteur. L'utilisation des services d'Érudit (y compris la reproduction) est assujettie à sa politique d'utilisation que vous pouvez consulter en ligne.

https://apropos.erudit.org/fr/usagers/politique-dutilisation/ 


\section{All Shall Yield to the Mulberry Tree: Of Toothpick Cases, Punch Ladles, Tobacco Stoppers, Inkstands, Nutmeg Graters, and the Legend of Shakespeare}

The Morus is a genus of deciduous and heterophyllous trees in the family Moraceae. As many as 150 species have been proposed but, while taxonomists agree that number is too high, the real answer remains indeterminate, and is complicated by the habit of Morus species to hybridize easily. Most respectable guesses range from seven to sixteen species, of which M. negra and M. alba are the most common. All the species are native to Asia, though both natural forces and imperial expansion have spread them throughout the world's tropical and temperate regions. Early in their life cycle, the Morus species grow quickly, which leads many to regard them as weeds. Once they reach maturity, though, their growth slows. It is not unusual for them to reach as much as fifteen meters in height, and they can live for hundreds of years. ${ }^{1}$ Morus had been brought to southern Europe even in antiquity, and appeared, at least in small numbers, in England in the Old English period. The Latin name morus made its way into Old High German as morbre and Old Saxon as mulbom; thence it combined with the word for its fruit to give us the Old High German mulberi and ultimately the English mulberry. The English word shows up before 1382 in the Wycliffite Bible,

1 For details of the biology of the mulberry, see Zheng Ting-zing et al., Mulberry Cultivation, trans. Chen Die-yun (Rome: Food and Agriculture Organization of the United Nations, 1988). 
where the Latin sycomoros is rendered as "Pe kyng yaf in to ierusalem ... cedres as longe mulberies." ${ }^{2}$

Perhaps it is less than entirely clear why I am dwelling on a tree, since dendrology rarely features large in discussions of eighteenth-century literature. As it happens, my interests are the mulberry tree's literary associations, for it shows up in a number of important works. Ovid, for instance, invokes mulberries in the story of Pyramus and Thisbe in the Metamorphoses - "arbor ibi niveis uberrima pomis/ardua morus, erat, gelido contermina fonti" ${ }^{3}$ - but the author of a more familiar version of that tale is a more important source for us. Shakespeare, following Ovid, depicts his "Thisby, tarrying in mulberry shade" in A Midsummer Night's Dream. In the same play, Titania tells the fairies to feed Bottom "Apricocks and Dewberries, /With purple Grapes, green Figs, and Mulberries." ${ }^{14}$ The real Shakespearean interest in mulberries, though, comes not from his works, but from his life - from a mulberry tree that Shakespeare himself supposedly planted.

With Shakespeare we move from horticulture to literary culture, which seems more appropriate to this forum than a biology lesson. But there is still no obvious connection with the eighteenth century. That Shakespearean mulberry, though, assumed new importance in the era we study; it can even be said, in a metaphorical way, to have come into existence only in the eighteenth century. The reason the story demands attention is that it makes visible many of the currents that run through eighteenth-century British intellectual life as a whole. What happened to this tree makes it a metonym for eighteenth-century notions of Shakespeare in particular and the past in general.

2 Cited in the Oxford English Dictionary, s.v. mulberry 1.a. $\beta$.

3 "Beneath the shadow of a tall mulberry tree, covered with snow-white fruit, close by a spring": see Ovid, Metamorphoses 4.89-90, in Ovid in Six Volumes, ed. G. Showerman et al., 2nd ed., 6 vols. (Cambridge, Mass.: Harvard Univ. Press, 1977-88).

4 A Midsummer Night's Dream, in The Riverside Shakespeare, ed. G. Blakemore Evans, 2nd ed. (Boston: Houghton Mifflin, 1997), 5.1.148 and 3.1.166-67. Shakespeare also has passing references to mulberries in Coriolanus, 3.2.79, Two Noble Kinsmen, 4.1.68, and Venus and Adonis, line 1103. It may be worth noting that another part of Bottom's diet, the fig - more than 800 species in the genus Ficus - comes from the same family as mulberries, the Moraceae. 
Legend has long held that Shakespeare, around the time he retired to New Place in Stratford, planted a mulberry tree in his garden. If this did in fact happen, it would probably have been in or shortly after 1609, an important date in the history of English mulberry cultivation. The tree was much discussed in the early seventeenth century, an age marked by a passion for moriculture. And passion is the right word, for the impetus behind moriculture was the prospect of sericulture, or the growth of silkworms. The Morus alba, or white mulberry, is native to China, and their leaves are the food of choice for silkworms. And silkworms give us silk, which has since antiquity been the archetypal luxury commodity. ${ }^{5}$

The desire for Chinese silk prompted several high-profile attempts to bring the Eastern tree to the West. Charles VIII of France - who earned the nickname "Charles the Affable" - travelled in 1494 to Naples, where some of his train "noted the richnes of the silke" in that part of Italy, and "at their return home did affect to prouide their houses of such commoditie. Afterwardes the warres of Italy ending, they sent to Naples, to fetch plants of Mulberries, which they placed in Prouence." ${ }^{\prime 6}$

In 1607, one Nicholas Geffe published a translation of Olivier de Serres's Perfect Use of Silk-Wormes, and Their Benefit with the Exact Planting, and Artificiall Handling of Mulberrie Trees, the first of many books to encourage the domestic production of exotic silk. Geffe insisted that he "hath these 7. yeeres entertained some part of my life, with an earnest or rather burning desire, ... to learn and find out the readiest and assuredst way, how to reare vp, nourish, \& feed Silk-worms, $y^{\mathrm{e}}$ most admirable \& beautifullest cloathing creatures of this world" (sig. A2 $2^{r}$ ). Silk was not his only concern - Geffe notes that "The reuenue of the white Mulberrie, consists not only in the leafe for to haue silke, but also in the bark, for to make ropes, course cloaths, mean, fine, and thinne"; this made the mulberry "the richest plant, and of most exquisite vse,

5 Silk was known in China by $3000 \mathrm{BCE}$, though it took some time for it to reach the West. The Roman Empire passed sumptuary laws restricting the use of silk, but to little effect. There are also several references to silk as a luxury good in the Bible: see Prov. 31:22, Ezek. 16:10-13, and Rev. 18:12. References are of course abundant in early English literature.

6 Olivier de Serres, The Perfect Use of Silk-Wormes, and Their Benefit with the Exact Planting, and Artificiall Handling of Mulberrie Trees Whereby to Nourish Them, and the Figures to Know How to Feede the Wormes, and to Winde off the Silke, trans. Nicholas Geffe (London, 1607), 4. 
whereof we yet haue had knowledge" (96). But silk was the main reason he had "Englished a most worthy \& select treatise of this subiect, written in French by D'oliuier de Serres L. of Pradel, with an annexed discourse of my owne continued proofes in England; \& the sufficiency therof, for the yeelding of abundant store of pure Silke" (sig. A2 ${ }^{v}$ ).

Geffe was not alone in this enthusiasm. His translation opens with a dedicatory poem by Michael Drayton, a work informed by a curiously botanical from of proto-nationalism:

The tree acquainting with the British soyle

And the true vse vnto our people taught

Shall trebble ten times recompence the toile

(From forraine parts) of him it hither brought. (sig. $\mathrm{A} 3^{\mathrm{v}}$ )

This was the cultural climate in which James I of England issued his proclamation of 1609 . James insisted that his intentions were entirely selfless: he stood to profit from import taxes on foreign silk and, by encouraging domestic production, he was giving up a revenue stream. But "We are content," he protested, "that our priuate benefit shall giue way to the publique, and therefore being perswaded that no well affected Subiect will refuse to put his helping hand to such a work as can haue no other priuate end in vs, but the desire of the wel-fare of our people, we haue thought good ... to require you ... to buye and distribute in that Countie, the number of ten thousand Mulberie plants, which shal be deliuered vnto them at our Cittie of \&c, at the rate of three farthinges the Plant." ${ }^{7}$

British silk never did become commercially viable. James I was hopeful in 1609; John Evelyn was still sanguine in Sylva; or, A Discourse of Forest-Trees in 1670 ("It may possibly be wonder'd by some, why we should insert this Tree amongst our Forest Inhabitants; but we shall soon reconcile our industrious Planter, when he comes to understand the incomparable benefit of $\mathrm{it}^{\prime \prime}{ }^{8}$ ); in 1707, John Mortimer's Whole Art of Husbandry hoped that the mulberry "would certainly turn to very great advantage if here made use of"; ${ }^{9}$ the second edition of the Encyclopæ-

7 Letellier, Instructions for the Increasing of Mulberie Trees (London, 1609), sig. A3 ${ }^{\mathrm{v}}-\mathrm{A} 4^{\mathrm{r}}$.

8 John Evelyn, Sylva; or, A Discourse of Forest-Trees, and the Propagation of Timber in His Majesties Dominions as it Was Deliver'd in the Royal Society the XVth of October, MDCLXII (London, 1670), 57.

9 John Mortimer, The Whole Art of Husbandry; or, The Way of Managing and Improving of Land (London, 1707), 347. 
dia Britannica in 1780 thought that "it in time might probably turn to a national advantage",; $;$ as late as 1884 , Henry N. Ellacombe noted that "it is now proposed to grow it in England" for "silk culture ... with a promised profit of from $£ 70$ to $£ 100$ per acre for the silk." ${ }^{11}$ Even in the 1930s and '40s there were attempts to grow English silk; the coronation gown and wedding dress of Queen Elizabeth (later the Queen Mother) included silk grown by Zoë, Lady Hart Dyke at Lullingstone Castle in Kent, as recorded in her memoir So Spins the Silkworm. ${ }^{12}$ But sericulture has never proven commercially viable in northwest Europe.

Whether this ill-fated desire for domestic silk is the reason for "Shakespeare's mulberry" is unclear. Whatever the reasons behind the Stratford mulberry, though, someone certainly planted a tree in what is known as the Great Garden at New Place; and, while we can never be certain, we can at least say it is not impossible that it was planted by Shakespeare. As Edmond Malone observed in 1790, "Shakspeare was perhaps the only inhabitant of Stratford, whose business called him annually to London; and probably on his return from thence in the spring of the year 1609 , he planted this tree." ${ }^{13}$

The tree then disappears from the written record for nearly a century and a half, only to emerge again in the 1750s, when New Place was bought by the Reverend Francis Gastrell, Vicar of Frodsham in Cheshire, as a summer home. Thomas Davies, David Garrick's first major biographer, reports in 1780 that "The mulberry-tree, planted by the poet's own hand, became an object of dislike to this tasteless owner of it, because it overshadow'd his window, and rendered the house, as he thought, subject to damps and moisture. ${ }^{14}$ In 1817, the physician Nathan Drake shamelessly plagiarized from Davies, but with a significant revision: for him, "The celebrated mulberry-tree planted by Shakspeare's hand became first an object of his dislike, because it subjected him to answer the frequent importunities of travellers, whose zeal might prompt them to visit it, and to hope that they might meet

10 Encyclopædia Britannica, 2nd ed., 10 vols. (1778-83), s.v. Morus.

11 Henry N. Ellacombe, The Plant-Lore E Garden-Craft of Shakespeare, 2nd ed. (London, 1884), 168.

12 Zoë, Lady Hart Dyke, So Spins the Silkworm (London: Rockliff, 1949).

13 Edmond Malone, ed., The Plays and Poems of William Shakspeare, 10 vols. (London, 1790), 1:119 $\mathrm{n}$.

14 Thomas Davies, Memoirs of the Life of David Garrick, Esq.: Interspersed with Characters and Anecdotes of His Theatrical Contemporaries, 2 vols. (London, 1780), 2:209. 
inspiration under its shade." ${ }^{15}$ Whether his complaints had to do with unwanted shade or unwanted tourists, though, Gastrell disliked the tree said to be Shakespeare's.

The first comprehensive telling of the story in print is by Edmond Malone, who in his milestone 1790 edition of Shakespeare reproduced Nicholas Rowe's biography of 1709 , adding a long footnote. After an account of the sales history of New Place, along with an account of Gastrell's bitter tax dispute with the corporation of Stratford, Malone notes,

Wishing, as it should seem, to be "damn'd to everlasting fame," he ... cut down Shakspeare's celebrated mulberry-tree, to save himself the trouble of shewing it to those whose admiration of our great poet led them to visit the poetick ground on which it stood. ${ }^{16}$

In 1756, in a fit of pique, Gastrell chopped the tree to the ground, and later knocked down New Place itself.

The mulberry tree, however, could not be removed from existence so easily. A clever local entrepreneur, Thomas Sharp, bought most of the wood from Gastrell. As Gastrell plays the role of supervillain in this story, Sharp embodies the archetype of the trickster. According to most accounts this Sharp was a watchmaker; others, though, make him out to be "an honest silversmith" or a carpenter. Whatever Sharp's day job, he began fashioning the mulberry wood into trinkets, and selling them to devotees of the Sweet Swan of Avon, now arriving in Stratford in ever greater numbers. Christian Deelman's description of this miraculous tree gives some idea of how effective Sharp was in marketing Shakespeare's cultural cachet:

The tree must surely have been of prodigious growth, for the list of objects which the ingenious carpenter made and sold is endless. At first, Sharp's products were fairly simple: little boxes, for snuff or for trinkets, tea-chests and small trunks. Then, as his imagination rose to the challenge, more and more domestic items found themselves fashioned from mulberry wood. ${ }^{17}$

15 Nathan Drake, Shakespeare and His Times, 2 vols. (London, 1817), 1:584.

16 Malone, The Plays and Poems of William Shakspeare, 1:118 n. "Damn'd to everlasting fame" is from Alexander Pope's account of Cromwell in An Essay on Man. There is more on Malone's interest in the mulberry in Sir James Prior, Life of Edmond Malone, Editor of Shakspeare: With Selections from His Manuscript Anecdotes (London, 1860), 141-42.

17 Christian Deelman, The Great Shakespeare Jubilee (New York: Viking Press, 1964), 50. 
These "domestic items" survived in great numbers in 1769, when David Garrick - then at the height of his fame - decided to organize the three-day Shakespeare Jubilee in Stratford. The event would begin a new era in Shakespeare worship: as Deelman writes, "The importance of the Jubilee in the history of Shakespeare's reputation can hardly be exaggerated. It marks the point at which Shakespeare stopped being regarded as an increasingly popular and admirable dramatist, and became a god" (7).

The ostensible purpose of the event was to dedicate a new Stratford town hall, and the town council thought Garrick's fame and vanity would make him a likely donor to assist in the construction. Francis Wheler, Stratford's Steward of the Court of Records, suggested in November 1767 that "It would be an Ornament to our New Town Hall at Stratford if we cou'd get from Mr. Garrick some very handsom bust, statue, or picture of Shakespear." He realized, though, that it might be necessary "to flatter Mr. Garrick into some such Handsom present," and therefore advised the township "to propose to make Mr. Garrick an Honourary Burgess of Stratford \& to present him therew ${ }^{\text {th }}$ in a Box made of Shakespeare's Mulberry tree" (Deelman, 60). The actor was intrigued by the idea, and began to organize a large-scale celebration to compensate for the world's neglect of Shakespeare's bicentenary five years earlier. $^{18}$

At the Jubilee Garrick gave the town council the requested statue, and they in return loaded him down with mulberry memorabilia: the box that housed the freedom of the town, a goblet, and other wooden trinkets were presented in a solemn ceremony. That wood was in fact at

18 This was not Garrick's first experience with Shakespearean mulberries. Some years earlier, in 1756 or ' 57 , he had commissioned Louis-François Roubiliac to sculpt a full-length figure of Shakespeare. Garrick supplied the marble but, as Roubiliac worked away at it, it became clear that it was marred with deep blue veins, leading to a dark smear on the lips. "What!" demanded Garrick. "Was Shakespeare marked with mulberries?" See John Thomas Smith, Nollekens and His Times: Comprehending a Life of That Celebrated Sculptor; and Memoirs of Several Contemporary Artists, from the Time of Roubiliac, Hogarth, and Reynolds, to That of Fuseli, Flaxman, and Blake (London, 1828), 97. Compare Deelman's account: "The marble which Garrick chose turned out to be faulty: full of blue veins. As the sculptor worked upon the head one of these appeared, giving the impression of a dark smear across the lips. 'Ha!' said Garrick, 'Mulberries!' Roubiliac had to replace the head with one cut from a new piece of marble at his own expense. The join can still be seen with a magnifying glass, just above the collar" (Deelman, The Great Shakespeare Jubilee, 98-99). 
the center of many of the festivities - the tree that had been chopped down thirteen years earlier still had plenty of life left in it.

2

It is time to turn from narrative to analysis. First, why all this obsession with a tree? Other Shakespearean locations and artifacts survived, and they received their share of adoration, but the mulberry tree became the center of eighteenth-century Bardolatry. It is no coincidence that it was organic - a tree, rather than a rock or a building - because late eighteenth-century conceptions of genius turned increasingly toward organic metaphors to explain the way a poet's mind worked. The word culture - originally a botanical metaphor - really came into its own for literary, artistic, and intellectual pursuits in just this era. A tree, of course, is perishable; this, too, is significant. The very fact that it was not only perishable but had perished made it a more poignant symbol of the eighteenth century's wistful awareness of the passage of time.

The fate of that tree is also an indicator of what was happening to England's cultural heritage - it was being packaged and transformed into a commodity. From the early seventeenth century mulberry trees were bound up with commerce; a domestic silk industry was supposed to avoid the need to put pounds sterling in Italian, French, or Chinese hands. But while all mulberries had commercial connections, Shakespeare's took the commercialization of culture to a new level, as Sharp began his work of transforming the firewood into a thousand gewgaws and tchotchkes. Garrick's play, The Jubilee, gives us a salesman enumerating his wares: "Toothpick cases," he cries, "needle cases, punch ladles, tobacco stoppers, inkstands, nutmeg graters, and all sorts of boxes made out of the famous Mulberry Tree. ${ }^{\prime 19}$ Christian Deelman has an even more extensive catalogue of items that came pouring out of Sharp's workshop:

Records are to be found listing cups and goblets, punch-ladles, card-cases, cribbage boards, tobacco-stoppers, tooth-pick cases, writing standishes, ink-horns and pen-cases, knives and forks, nutmeg-graters, knitting sheaths, comb cases,

19 Garrick, The Jubilee, in The Plays of David Garrick, ed. Harry William Pedicord and Fredrick Louis Bergmann, 7 vols. (Carbondale: Southern Illinois Univ. Press, 198082), 2:111. 
and many more specifically local objects, such as carvings of Shakespeare's monument in the church. (p. 50)

It is curious to see tobacco stoppers and nutmeg graters on this list. The mulberry had been brought to England to protect the country against damaging imports of exotic foreign products - the nation's wealth was being sent out of the country, and this was worrisome. But by the $1760 \mathrm{~s}$ the same tree is being used to render imported luxury goods more useful - tobacco from the North American colonies and nutmeg from the Moluccas Islands in Indonesia. It represents a new attitude toward the products of empire.

This kind of commodification was happening to the tree at the same time it was happening to Shakespeare in particular, and to the cultural past in general. Commerce began to be the inseparable companion of high culture. It seems every Stratford merchant was eager to profit from the Jubilee. On the first day, for instance, one newspaper carried the following advertisement for a tooth powder under the heading, "For the STRATFORD JUBILEE":

To those who would appear really elegant there, or elsewhere, the Albion Dentifrice is recommended, as without a sweet Breath and clean Mouth (which no cloying Odours of perfumed Essence will give) there can be no communicative Satisfaction. This Dentifrice in a few Times using will evince its superior Efficacy and Elegance; it has no Taste, yet it will make the Teeth white and beautiful, the Saliva pure and balsamic, all which it does by concocting the acrimonious Juices of the salival Glands.

As Michael Dobson writes, "What is most striking" about these things at the Jubilee "is not their kitsch strangeness but their unnerving familiarity." ${ }^{20}$

This commodification of the mulberry tree can be said to mark the very beginning of our "heritage industry," a collocation that shows how cash and culture have become inseparable. Stratford is now the second most-visited city in England, after only London, and every shop, pub, and bed-and-breakfast in Warwickshire knows the monetary value of their favorite son. Shakespeare's Stratford, inaugurated at the Jubilee in 1769 , provided the model for literary tourism not only throughout England, but throughout the world. The author's house as museum,

20 Michael Dobson, The Making of the National Poet: Shakespeare, Adaptation and Authorship, 1660-1769 (Oxford: Oxford Univ. Press, 1992), 15. 
the blue plaques marking famous former owners, the trinkets in the gift shops - all derive from this first literary commemoration. The Jubilee began in 1769, and has not ended yet.

Stratford, that is to say, had become the object of a pilgrimage, drawing palmeres for to seken straunge strondes, the hooly blisful mulberry to seke. Garrick put himself at the center of the event, and promoted a song called "The Mulberry Tree," which deserves to be called a hymn in the new secular religion of Shakespeareanism:

Behold this fair goblet, 'twas carved from the tree,

Which, O my sweet SHAKESPEARE, was planted by thee;

As a relick I kiss it, and bow at the shrine,

What comes from thy hand must be ever divine!

And then the whole chorus joins in:

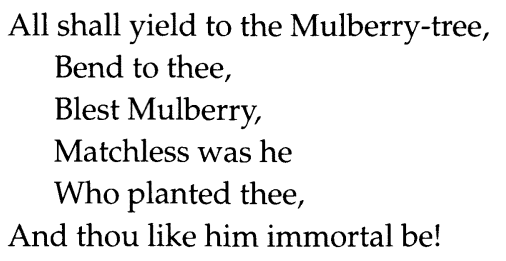

(Boswell, who reported on the Jubilee in the London Magazine, paused long enough from anonymously praising himself to write about the entertainment at dinner in the amphitheatre: "Here the company dined exceedingly well between three and four. Between five and six the musical performers appeared, and entertained us with several of the songs in Shakespeare's Garland composed for the occasion. Sweet Willy $O$, tender and pathetic. The Mulberry tree, of which the chorus is very fine." ${ }^{21}$ ) The other stanzas - eight in all - are equally exuberant. Shakespeare's mulberry tree dominates the "trees of the forest, so rampant and high"; it beats out the "royal" oak, "Britain's great boast" - all because "The Genius of SHAKESPEARE out-shines the bright day,/ More rapture than wine to the heart can convey." The song ends with a call for everyone in the audience to join in the ritual, at once poetic, religious, and nationalistic:

21 "A Letter from James Boswell, Esq; on Shakespeare's Jubilee at Stratford-upon Avon," The London Magazine, Sept. 1769. 
Then each take a relick of this hallow'd tree,

From folly and fashion a charm let it be;

Fill fill to the planter, the cup to the brim,

To honour the country, do honour to him.

And then all join, once more, in the chorus: "All shall yield to the Mulberry-tree." ${ }^{\prime 22}$

The religious language is positively overdetermined - relick, divine, blest, immortal, and hallow'd all within a few lines. Never before had any English writer been the object of such veneration; the pattern that guided the new style of literary adoration was therefore lifted from religious adoration. Shakespeare's mulberry tree had become a modern equivalent of the True Cross, and the Bard the secular equivalent of Christ. Cowper put it in exactly the right language in book 6 of The Task:

The mulb'ry tree was hung with blooming wreaths,

The mulb'ry tree stood center of the dance,

The mulb'ry tree was hymn'd with dulcet airs,

And from his touchwood trunk, the mulb'ry tree

Supplied such relics, as devotion holds

Still sacred, and preserves with pious care. ${ }^{23}$

The likening of the mulberry trinkets to religious relics was widespread in the nineteenth century. An anonymous Account of the Principal Pleasure Tours in England and Wales - the title alone suggests the degree to which literary tourism had become a mass-market phenomenon recorded of a resident of Stratford, "This old lady has also ample supply of Shakespeare's mulberry tree, which, like the wood of the true cross, seems to have the power of self-multiplication; for there has been more of it carried away than would build a ship of the line." ${ }^{24}$ And in 1827 , John Wilson noted that "even fictitious memorials have charms to rivet the attention and fascinate the regard. Goblets, snuff-boxes, and baubles of various descriptions, sculptured [sic] from wood of the real

22 "The Mulberry-Tree," in David Garrick, Songs, Chorusses, Ec. Which Are Introduced in the New Entertainment of the Jubilee, at the Theatre Royal, in Drury-Lane (London, 1769), 5-7.

23 William Cowper, The Task, a Poem, in Six Books (London, 1785), 266.

24 An Account of the Principal Pleasure Tours in England and Wales (London, 1822), 366. 
mulberry-tree, have been issued in such quantities, that a forest would have been required for the production of the objects in question. ${ }^{\prime 25}$

The theme was developed by another writer in 1805: a young man describes his visit of 1792 to "an old shopkeeper, who [was] ... in possession of the remains of the mulberry tree, together with tobacco stoppers, busts, wafer seals, \&c., all carved from the wood, which (like the pieces of the real cross in catholic countries) have so multiplied that I much fear a dozen full-grown mulberry trees would scarcely suffice to produce the innumerable mementoes already extant." His companion "having purchased some of these bagatelles, and a goblet which had certainly been carved many years back, and in all probability from the original tree, for which he gave an adequate price, we left this manufacturer of Shaksperian relics." ${ }^{26}$

This reason this last writer has a claim on our attention is that his name was William Henry Ireland, the most famous hoaxer in the history of Shakespeare, and the dupe who paid good money for manufactured relics was his father Samuel Ireland, a devoted but perennially naïve Bardolater. Shortly after that trip unpublished letters show Ireland père negotiating to get his hands on even more fragments. A letter from $\mathrm{M}$. S. Hunt - presumably a relative of the William Hunt who had lived on the site of New Place after Gastrell pulled the old house down expresses regret to Samuel Ireland: "With respect to the Mulberry," he apologizes, "I wish I could accommodate you, but I have but a very small bit, not a quarter enough for the purpose you want it, nor do I know of any person who has a sufficient quantity of the real Mulberry or I would endeavour to procure it for you. ${ }^{27}$ Somehow, though, Samuel Ireland managed to get his hands on some of the relics; in the posthumous sale catalogue of his estate appear two items, lot 34, "A tooth-pickcase cut with vine leaves, and the arms of Shakspeare made of the mulberry-tree," sold to James Boaden for half a guinea, and lot 46, "A goblet made of Shakspeare mulberry tree and mounted in

John Wilson, Shaksperiana: Catalogue of All the Books, Pamphlets, Ec. Relating to Shakspeare (London, 1827) $\mathrm{v}$.

26 William Henry Ireland, Confessions of William-Henry Ireland (London, 1805), 20.

27 M. S. Hunt to Samuel Ireland, 15 Sept. 1795, in Huntington MS 287179, vol. 2, fol. 33. 
silver," which went for an extravagant $£ 6 .{ }^{28} \mathrm{~W}$. H. Ireland was very fond of the item; he sketched it and sent the illustration to a friend. ${ }^{29}$ Young Ireland also preserved an entry from an undated sale catalogue among his papers, under the heading "SHAKESPEARE CUP":

A very Elegant Cup made from the Mulberry Tree planted by Shakspeare, beautifully carved on the sides, with a Medallion of Shakspere, and his Arms; executed by Sharpe of Stratford upon Avon, at the time the tree was cut down, $£ 31$. 10s. ... Nothing connected with the name of Shakspeare can ever be indifferent to the British Nation; since he has raised our Drama to the highest pitch of excellence, and by his exquisite delineations of nature and character, shown a versatility of genius, which has never been equalled, either at home or abroad. Lloyd has justly observed "to copy nature is to copy him!" The Cup, which is now presented to the public, will therefore, be esteemed of far greater value in its simple form of wood, than a goblet carved from the most precious metals; when they learn, that it is constructed from the Mulberry Tree planted by the hand of Shakspeare! They, who are deficient in enthusiasm, may imagine, that too much has been written on the subject of a Cup. Had this Great Genius himself been living, had we even manuscripts of his Plays to offer, much less would have been required,

But now he's gone, and my idolatrous fancy

Must sanctify his relicks.

All's Well that Ends Well, Act I. Sc. $1 .^{30}$

That goblet is an interesting one - a relic that is also a drinking vessel, which inevitably suggests the Holy Grail, just as the dark red stain produced by mulberries suggests blood. According to Ovid's telling of the Pyramus legend, it was the lovers' blood that turned the white berries purple. As Deelman points out, even the famous goblet given

A Catalogue of the Books, Paintings, Miniatures, Drawings, Prints, and Various Curiosities the Property of the Late Samuel Ireland, Esq., 2 vols. (London, 1801), 1:3-4. W. H. Ireland tells the story of his father's purchases in an unpublished autobiography written around 1802-3, A Full and Explanatory Account of the Shaksperian Forgery by Myself the Writer William Henry Ireland: Illustrated with Picturesque Family Documents, Ec., 64-65. The manuscript is now in the Hyde Collection at Harvard University.

29 Princeton MS RTC01 no. 176, p. 41. I describe the manuscript in detail in "William Henry Ireland's Authentic Forgeries," Princeton University Library Chronicle 66, no. 1 (Autumn 2004): 79-96.

30 Rosenbach EL3 f.I65i MS4 vol. 1, 114 
to Garrick had "surprising powers of self-multiplication," no doubt owing to the twin associations - Shakespeare's tree, once owned by Shakespeare's greatest interpreter. As Deelman traces it,

Garrick in 1773 gave to a friend, the Rev. Evan Lloyd, a mulberry drinking cup. But another one turned up in the sale of his wife's possessions in 1823, this time clearly described as the very one used at the Jubilee. It fetched the incredible price of $£ 127$ 1s. Od. The Garrick Club, however, has yet another goblet; of course, the very one used at the Jubilee. This was presented to Mrs. Colman, with an epigram by Garrick himself, in 1776 . By 1857 at least three goblets were doing the rounds of the sale rooms. ${ }^{31}$

It is significant that a prominent forger would show up at this point in the story, for relics almost beg for fraud. A full decade before the Jubilee, even, in February 1759, Thomas Hull wrote to William Shenstone, proudly declaring, "I Received the Tobacco-Stopper, which my Friend Mr. PERCY bought at Moody's Shop, and also the Letter, to authenticate its being made of the Tree he mentioned." But the qualification makes it clear that he suspected iniquity among those hawking bits of tree. Why should a letter, a certificate of authenticity, put his mind at ease? Mostly, no doubt, because he wanted to believe, and any scrap of paper would have done the trick. But he was "pretty well assured of the Truth thereof, having lately seen Mr. HовBS of Birmingham, who informs me, that he has a Piece of the same Tree, which he brought from Stratford, in his Possession." ${ }^{32}$

This concern with the authenticity of the artifact reminds us that the eighteenth century was standing at the beginning of the age of mechanical reproduction - the Industrial Revolution was ramping up, in the Midlands not far from Stratford - and it is therefore only natural that we should see so much of an aura invested in a relic of the authentic, pre-industrial past. But by the time of the Jubilee in 1769, stories of bogus mulberry relics were circulating widely. Garrick's play on the Jubilee includes this warning from one character to another: "Don't buy of that fellow, your honor, he never had an inch of the Mulberry Tree in his life. His goods are made out of old chairs and stools and colored to cheat gentlefolks with. It was I, your honor, bought all the true Mul-

31 Deelman, 199. This count seems to exclude the one that showed up in the Samuel Ireland estate sale.

32 Thomas Hull, Select Letters between the Late Duchess of Somerset, Lady Luxborough, ... and Others, 2 vols. (London, 1778), 1:251. 
berry Tree. Here's my affidavit of it." But the other would-be salesman comes back, "Yes, you villain, but you sold it all two years ago, and you have purchased since more mulberry trees than would serve to hang your whole generation upon. He has got a little money, your honor, and so nobody must turn a penny or cheat gentlefolks but himself" (The Jubilee, in Plays, 2:112). All of this suspicion led Thomas Sharp to sign a deathbed affidavit on 14 October 1799: "the Reverend Jno Gastrel," he declared, - it was actually Francis, but let that pass -

cut down the said Mulberry-tree, and cleft it as fire-wood; when the greatest part of it was purchased by me, the said Thos. Sharp; who, out of a sincere veneration for the memory of its celebrated planter, ... worked it into many curious toys and usefull articles from the same. And I do hereby declare, \& take my solemn oath, upon the four Evangelists, in the presence of Almighty God, that I never had worked, sold, or substituted any other wood, than that what came from, \& was part of the same tree. ${ }^{33}$

It would be presumptuous to judge the fate of Sharp's soul, but the Evangelists were probably unimpressed by his oath. As Ian Ousby points out in his account of the rise of tourism in Britain, "A few days later Mr Sharp took his conscience to the grave with him." ${ }^{34}$

Precisely because adoration leads so easily, even inevitably, to fraud, there was a satirical tradition that poked fun at the excesses of Shakespearean idolatry. Consider a minor English poet, Edward Lovibond, who included "The Mulberry-Tree: A Tale" in his Poems on Several Occasions. That work brings Samuel Johnson and Garrick to Stratford together, even though Johnson pointedly stayed in London during the Stratford Jubilee of 1769, much to Boswell's regret. Facts, it seems, matter little in this deflation of hyperbolic adulation:

For LONDON's rich city, two STAFFORDSHIRE swains,

Hight JOHNSON, hight GARRICK, forsaking their plains,

33 Robert Bell Wheler, History and Antiquities of Stratford-upon-Avon (Stratford-uponAvon, 1807), 137-38 n.

34 Ian Ousby, The Englishman's England: Taste, Travel and the Rise of Tourism (Cambridge: Cambridge Univ. Press, 1990), 42. 
Reach'd SHAKESPEARE's Own STRATFORD, where flows by his tomb An Avon, as proudly as Tiber by Rome.

Now GARRICK, (sweet imp too of Nature was he,)

Would climb and would eat from his MULBERRY-TREE. ${ }^{35}$

Lovibond's mulberry provides the opportunity for some scatological humor:

His speech pleas'd the vulgar, it pleas'd their superiors,

By JOHNSON stopt short, - who his mighty posteriors

Applied to the trunk - like a SAMPSON, his haunches

Shook the roots, shook the summit, shook stem, and shook branches!

All was tremor and shock! - now descended in showers

Wither'd leaves, wither'd limbs, blighted fruits, blighted flowers!

(pp. 133-34)

He responds to the over-the-top enthusiasm with a correspondingly splenetic sarcasm:

That to STRATFORD's old MULBERRY, fairest and best,

The Cedars of EDEN must bow their proud crest:

Then the fruit - like the loaf in the TuB's pleasant Tale,

That was fish, flesh, and custard, good claret, and ale -

It compriz'd every flavour, was all, and was each,

Was grape, and was pine-apple, nectarine and peach;

Nay he swore, and his audience believ'd what he told,

That under his touch it grew apples of gold. (132-33)

And William Cobbett, who often confessed he never saw the attraction in Shakespeare, went out of his way to puncture the pretensions of early Bardolaters:

When I was a very little boy, there was a jubilee in honour of SHAKSPEARE, and as he was said to have planted a Mulberry-tree, boxes, and other little ornamental things in wood, were sold all over the country, as having been made out of the trunk or limbs of this ancient and sacred tree. We Protestants laugh the relics so highly prized by Catholics; but never was a Catholic people half so much duped by the relics of saints, as this nation was by the mulberry tree, of which,

35 Edward Lovibond, Poems on Several Occasions (London, 1785), p. 130. The volume appeared ten years after Lovibond's death in 1775 . 
probably, more wood was sold than would have been sufficient in quantity to build a ship of war, or a large house. ${ }^{36}$

This withering skepticism is typical of one strand of thought regarding the mulberry tree. We have seen people prepared to believe in its authenticity without asking questions, and others who were convinced every bit of it was bogus. There were also a few who suspected the relics, but still retained enough spirit to be willing to play the game. Writing of a visit to Stratford in 1809, Elizabeth Isabella Spence recounted, "I brought away a small piece of what I was told was a part of the celebrated mulberry tree, but am rather incredulous on that subject." ${ }^{37}$

Scholars, though, longed to know for sure, depending on something more than faith or cynicism. But even being sure that this tree existed was no easy task. Gastrell's contemporaries depended on tradition - which is to say oral tradition - and the mid-eighteenth century developed a genuine obsession with the dangers of orality. Many of the most prominent critics were duped by James Macpherson's Ossianic epics, which were backed by oral tradition, at almost exactly the same time; many other stories once accepted implicitly were now being challenged as late inventions. We see the same thing happening even in the courtroom: seventeenth-century English criminal law, like that on the Continent, almost always depended on an eyewitness prepared to swear to the fact - the only way to provide positive proof, and for most crimes the only way to secure a conviction. But the eighteenth century gives us the beginnings of a systematic evaluation of the worth of circumstantial evidence - the evidence of things, as it was often called. Many critics and legal theorists started to consider it the equivalent of positive evidence; in 1785, William Paley even went so far as to argue that it was inherently superior, challenging the "popular maxim

36 William Cobbett, Advice to Young Men, and (Incidentally) to Young Women, in the Middle and Higher Ranks of Life (New York, 1833), 68-69.

37 Elizabeth Isabella Spence, Summer Excursions, 2 vols. (London, 1809), 1:109. Compare Washington Irving's strange combination of skepticism and credulity regarding a chair said to have been Shakespeare's: "I am always of easy faith in such matters, and am ever willing to be deceived, where the deceit is pleasant, and costs nothing. I am therefore a ready believer in relics, legends, and local anecdotes of goblins and great men; and would advise all travellers who travel for their gratification to be the same. What is it to us whether these stories be true or false, so long as we can persuade ourselves into the belief of them, and enjoy all the charm of the reality?" See The Sketch Book of Geoffrey Crayon, Gent, ed. Haskell Springer (Boston: Twayne Publishers, 1978), 210-11. 
... 'that circumstantial evidence falls short of positive proof.' This assertion," Paley said, "in the unqualified sense in which it is applied, is not true. A concurrence of well-authenticated circumstances composes a stronger ground of assurance, than positive testimony, unconfirmed by circumstances, usually affords. Circumstances cannot lie. ${ }^{138}$ And many of the techniques for tracking down, identifying, authenticating, and interpreting circumstantial evidence - usually taking the form of documents and other material evidence - grew out of eighteenth-century Shakespearean scholarship, just as many strands of Shakespearean scholarship grew out of contemporary legal theory. It is no coincidence that Edmond Malone - who gave the first comprehensive history of the mulberry tree, and who worked to discredit the forgeries of William Henry Ireland - was a lawyer. Consider the language in his discussion of the mulberry tree, filled with the kinds of circumstantial facts that a barrister would be expected to produce in a court of law: "That Shakspeare planted this tree," he wrote, "is as well authenticated as any thing of that nature can be." ${ }^{\prime 39}$ Here he is simply echoing William Gilbert, whose seminal work The Law of Evidence, one of the first works to consider how to weigh circumstantial evidence, decreed that "The first ... and most signal Rule, in Relation to Evidence, is this, That a Man must have the utmost Evidence, the Nature of the Fact is capable of. ${ }^{\prime 40}$ Malone goes on to adduce specific facts and to establish a series of links across time, letting observers in 1790 ascertain a fact of 1609:

The Rev. Mr. Davenport informs me, that Mr. Hugh Taylor, (the father of his clerk,) who is now eighty-five years old, and an alderman of Warwick, where he at present resides, says, he lived when a boy at the next house to New-Place; that his family had inhabited the house for almost three hundred years; that it was transmitted from father to son during the last and the present century, that this tree (of the fruit of which he had often eaten in his younger days, some of its branches hanging over his father's garden,) was planted by Shakspeare. ${ }^{41}$

His desire to establish an authoritative chain of testimony stretching back from the present to some point in the past is representative of

38 William Paley, The Principles of Moral and Political Philosophy (London, 1785), 551.

39 Malone, The Plays and Poems of William Shakspeare, 1:118 n.

40 Gilbert, The Law of Evidence (London, 1756), 4.

41 Malone, The Plays and Poems of William Shakspeare, 1:118 n. 
eighteenth-century Britain's desire to establish an authoritative means of distinguishing genuine from false claims about its past. ${ }^{42}$

I would like to end with some meditations on the cultural work done by the vilification of the nefarious Gastrell. If we were to film the moment when the tree fell, the camera angle would widen to show the desolation, accompanied by brooding minor or diminished chords. The mulberry's original mourners had no film to look to, so they found their analogues in literary renditions of sacred history. Destroying the mulberry was for many of them like the eating of the fruit in Eden another tragic story with a tree at its center. Eve's

rash hand in evil hour

Forth reaching to the Fruit, she pluck'd, she eat:

Earth felt the wound, and Nature from her seat

Sighing through all her Works gave signs of woe,

That all was lost. ${ }^{43}$

If the comparison seems forced, I am not the first to make it; in 1780, Davies borrowed the Miltonic phrase "in evil hour" verbatim when describing Gastrell's act of blasphemy. There is another defining moment in sacred history, after Christ has spoken the last of his seven words on the cross - itself often figured as a tree:

42 For concrete examples of a literary scholar trying to determine the authenticity of mulberry-wood relics, see the "Mulberry Block Papers," in the University of Pennsylvania's Furness MSS. The papers record exchanges among Horace Howard Furness, James Orchard Halliwell, John Sartain, Mary Sophia Quincy, William Hunt, and E. F. Flower from 1864 to 1866; the correspondents try out various evidentiary standards for authenticating the block of wood Furness had obtained. Most were eager to reassure the nervous purchaser. "Your block of the mulberry tree," wrote Halliwell on 22 Nov. 1866, "is better authenticated than one piece in a thousand said to be genuine: I have no evidence that the Corporation gave Garrick such a block, but it is not at all unlikely that they did."

43 Milton, Paradise Lost, 9.780-84. It may be worth noting that Milton too was credited with planting a mulberry tree at his college in Cambridge, though when the stories first reach print - The New Cambridge Guide; or, A Description of the University, Town, and County of Cambridge (Cambridge, 1804), 53, is the first example I have been able to identify - the tree was still standing. This version grounds its claims only in oral tradition, as do all the other early accounts of the Miltonic mulberry. 
And, behold, the veil of the temple was rent in twain from the top to the bottom; and the earth did quake, and the rocks rent; And the graves were opened; and many bodies of the saints which slept arose. ${ }^{44}$

Boswell attributed the wicked act of tree-destruction to Gastrell's "Gothick barbarity." ${ }^{45}$ The stories of his "desecration" of Shakespeare's tree and house continued to be told over the decades, becoming more egregious with each retelling. In 1789 John Adams retold Davies's story, declaring that "A man of taste in such a situation ... would have congratulated himself on his good fortune, and have deemed himself the happiest of mortals." Perhaps in 1789, but not in 1752, when Gastrell moved in. Boswell, Davies, and Adams, though, could not conceive of a time when Shakespeare was anything less than divine: Gastrell must have been a moral monster. As a result, "The mulberry-tree, planted by the poet's own hand, became an object of dislike to this tasteless owner of it. ... In an evil hour" - there again, the Miltonic formula "the unhappy priest ordered the tree to be cut down." As Davies and Adams tell the story, "The people of Stratford, who had been taught to venerate every thing which related to the immortal Shakespeare, were seized with grief and astonishment when they were informed of the sacrilegious deed." In the ensuing lamentations, "The miserable culprit ... was obliged at last to leave the town, amidst the curses of the populace, who solemnly vowed never to suffer one of the same name to reside in Stratford." ${ }^{46}$

The Victorians became even more extravagant in their castigation of Gastrell. The Official Programme of the Jubilee celebration of 1864, scheduled to mark Shakespeare's tercentenary, compared the English clergyman both to the violent hordes that overran the Roman Empire and to an ancient critic who had the nerve to criticize Homer, denouncing him as "Gastrell, that Goth, deserving all the ignominy heaped upon the memory of Zoilus." By 1864 Gastrell was long dead - it had been more than a century since he knocked down New Place - but the worshipers

44 Matt. 27:51-52. The association of the cross with a tree goes back more than a millennium in English; the OED gives its first example from before the year 1000. James Boswell, The Life of Samuel Johnson, LL.D., ed. G. B. Hill, rev. L. F. Powell, 6 vols. (Oxford: Clarendon Press, 1934-64), 2:470.

46 Davies, Memoirs of the Life of David Garrick, 2:209-10; repeated, with minor variations, in John Adams, Anecdotes, Bons-mots, and Characteristic Traits of the Greatest Princes, Politicians, Philosophers, Orators, and Wits of Modern Times (London, 1789), 307. 
of Shakespeare knew how to hold a grudge, and even to extend it into the next world. The writer's curse on the dead man's bones is remarkable for its vituperation, but is not out of the mainstream of Victorian thought:

If the Church has among her ceremonies any ceremony opposite to canonisation which might carry excommunication beyond the grave, and perpetuate the infamy of the sacrilegious, she ought to have long since exercised it in respect of the Rev. Mr. Gastrell — (what a profanation of the word reverend!) — and placed his name first upon the calendar of obloquy. ${ }^{47}$

I have argued elsewhere that eighteenth-century Britons derived their sense of modernity from a contrast with what was variously called "the last age" or "the age of Elizabeth" - as the "modernity" that was proclaimed by the humanists of the fifteenth and sixteenth centuries became unwieldy, and had to be split in two. ${ }^{48}$ I have argued that it was eighteenth-century Britain's habit of measuring itself against the age of Shakespeare that produced the historical distance necessary to inaugurate a new notion of modernity - that the age of Johnson discovered or invented its identity only when it could view the age of Elizabeth as another age, an age whose end marked the beginning of their own. In this light, it seems the eighteenth century needed the dastardly Gastrell, whose outrage on Shakespeare's memory embodies that scission between once-upon-a-time and modernity. The moment in which he cut down the tree was literally epochal - it was the beginning of a new era. When the tree fell, England became modern - no longer part of the age of Elizabeth, but a new age, and perhaps a lesser one, but one that could derive inspiration from the earlier epoch.

What I have been arguing is that this tree has much to teach us: we can use it as a kind of base from which we can make sorties and scouting missions into the territory of the larger cultural history. The manufacture of relics shows us some of the earliest intrusions of capitalism into packaged high culture, as well as the transfer of the kind of adoration

47 The Official Programme of the Tercentenary Festival of the Birth of Shakespeare, to be Held at Stratford-upon-Avon, Commencing on Saturday, April 23rd, 1864: Also, an Account of What Is Known of the Poet's Life: A Guide to the Town and Neighbourhood of Stratfordupon-Avon: And Sundrie Other Matters Just Now of Publicke Interest Relating Thereto (London, 1864), 22-23.

48 See The Age of Elizabeth in the Age of Johnson (Cambridge: Cambridge Univ. Press, 2003), esp. Introduction. 
once reserved for sacred figures to the secular world of literary culture, and from religious pilgrimages to holiday tours. The relocation of the center of Bardolatry from London - the site of Shakespeare's professional triumphs - to Stratford shows us the shift in attention from the professional to the native genius, which is in keeping with the Romantic "Great Man" conception of literary excellence, as well as the newfound fascination for childhood as the matrix of the later literary prominence, such as we see in Rousseau and, a little later, in Wordsworth. And I remain convinced other lessons are lurking there. The story of the mulberry tree has been told many times, but usually as nothing more than a curiosity. This is a pity, for Shakespeare's tree can teach us valuable lessons about eighteenth-century Britain's relationship to its own past.

JACK LYNCH

Rutgers University 